\title{
KETERAMPILAN KEPALA SEKOLAH DALAM PROSES PENGAMBILAN KEPUTUSAN
}

\author{
UTARI OCTAVIANI \\ 16002103 \\ Utarioctaviani98@gmail.com
}

\begin{abstract}
Dalam setiap organisasi baik itu di lembaga pendidikan, pemerintah, kesehatan, dan lainnya pastinya ada seorang pemimpin. Jika di lembaga pendidikan kita mengenal nya dengan kepala sekolah. Untuk menjadi seorang kepala sekolah atau pemimpin dalam suatu organisasi pastinya harus memiiki keterampilan dalam proses pengambilan keputusan. Mengambil suatu kepetusan tidaklah mudah bagi seseorang pemimpin, ia harus memiliki pengetahuan luas mengenai proses pengambilan keputusan, memiliki banyak pengalaman mengenai suatu masaalah yang harus diselesaikkan, mampu menganalisis setiap masalah yang ada adi organisasi, mempertimbangkan segala kelebihan atau kelemahan untuk solusi permasalahan, dan lain sebagainya. Dan itu harus benar-benar teliti agar keputusan yang ditetapkan tidak memiliki resiko yang besar. Maka dari itu bagi seorang pememimpin atau kepala sekolah diperlukan sekali keterampilan dalam proses pengambilan keputusan. Proses pengambilan keputusan pada umunya itu terdiri dari enam tahapan, dimana tahapannya yaitu (1) identifikasi masalah, yaitu seorang kepala sekolah bisa mengetahui masalah apa yang sudah sangat kronis yang harus diprioritaskan untuk diselesaikan; (2) mencari alternatif, yaitu kepala sekolah dapat melakukannya sendiri atau juga dari para guru atau staf untuk mengembangkan beberapa alternatif yang dapat dilakasanakan; (3) analisis alternatif, yaitu kepala sekolah harus mengevaluasi atau analisis satu persatu secara teliti apakah alternatf cocok untuk memecahkan masalah; (4) memutuskan alternatif, yaitu memilih satu dari beberapa alternatif untuk dijadikan keputusan yang terbaik; (5) implementasi keputusan, yaitu melaksanakan pilihan alternatif yang telah diputuskan; (6) evaluasi, yaitu kepala sekolah melakukan pengukuran berkala mengenai apakah hasil yang diperoleh sesuai apa yang direncanakan.
\end{abstract}

\section{Keywords: Kepala Sekolah, Proses Pengambilan Keputusan}

\section{PENDAHULUAN}

Mengambil keputusan merupakan salah satu bagian dari kegiatan kepala sekolah. Pengambilan keputusan tidak lah mudah bagi seorang pemimpin atau kepala sekolah dalam suatu organisasi, karena keputusan yang akan diambil menyangkut kepentingan bersama atau orang banyak jadi tidak bisa sembarangan mengambil keputusan begitu saja karena ada pedoman dalam mengambil sebuah keputusan.

Kepala sekolah bisa dikatakan orang yang sangat berpengaruh dalam sekolah karena ia harus membuat keputusan yang tepat. Berhasil atau gagalnya uatu organisasi itu adalah hasil dari pembuatan keputusan oleh seorang pimpinan. Pimpinan merupakan orang yang harus memutuskan dengan baik, mampu mempertimangkan segala sesuatunya dengan baik agar bawahannya tidak salah langkah dalam melakukan dalam suatu kegiatan.

Sama hal nya seperti pada lembaga pendidikan, maju atau tidak nya sekolah tersebut itu ditentukan oleh pembuatan keputusan oleh kepala sekolah.

Keputusan yanng diambil pasti ada dasarnya yaitu adanya permasalahan atau persoalan dalam pendidikan.

Dalam mengambil keputusan yang baik dan tepat dibutuhkanya sebuah keterampilan agar keputusan yang diambilnya dapat memecahkan masalah 
suatu sekolah. Maka dari itu kepala sekolah harus meningkatkan lagi keterampilan dalam proses pengambilan keputusanya, agar hasil yang diperoleh itu tepat. Kepala sekolah juga melibatkan dasar-dasar pengambilan keputusan. Karena keputusan yang diambil bisa berdasarkan intusi/perasaaan, pengalaman, fakta, wewenang, dan rasional.

\section{PERMASALAHAN}

Namun demikian selama ini di sekolah-sekolah ada beberapa kepala sekolah yang kurang terampil dalam proses pengambilan keputusan. Karena disebabkan kurangnya pengalaman, intuisi yangkuat, atau yang lainnya sehingga mengakibatkan ketidaktepatan dalam mengambil sebuah keputusan.

\section{KAJIAN TEORITIS DAN PEMBAHASAN}

\section{Pengertian Keterampilan Pengambilan Keputusan}

Ketarampilan adalah suatu kemampuan yang dimiliki oleh setiap orang. Degan keterampilan sesuatu yang ia punya apapun kegiatannya pastinya akan membuahkan hasil yang baik. Karena keterampilan itu butuh dilatih agar kita bisa meraih keterampilan apa yang ingin kita inginkan. Dengan keterampilan yang dimilki seserang itu dapat mempengaruhi orang lain, karena kita tahu apa yang ingin dikerjakan dengan bermodal memiliki keterampilan. Tetapi untuk kemampuan, kita tidak hanya bisa mengandalkan keterampilan saja, tetapi pengetahuan dan sikap, ie kreativitas, innisisatif, dan tingkat emosional juga harus juga seimbang agar apa tujuan kita tercapai.

Kepala sekolah adalah seorang pimpinan dalam lembaga pendidikan. Kepala sekolah merupakan tenaga kependidikan yang memiliki jabatan paling tinggi di sekolah. Untuk menjadi kepala sekolah tidak lah mudah, karena setiap harinya kepala sekolah selalu memutuskan segala sesuatu yang terjadi di sekolah.
Karena maju atau tidak nya sekolah itu ditentukan oleh pembuatan keputusan yang dilakukan oleh kepala sekolah itu sendiri.

Untuk mengambil sebuah keputusan kepala sekolah tidak hanya bisa bermodal dengan pengetahuan atau teori saja tetapi harus memiliki ketampilan juga sikap yang bijaksana dalam mengambil keputusan. Dalam mengambil keputusan diperlukan kepala sekolah yang memiliki sikap yang bijaksana, arif atau pintar untuk mempertimbangka mana yang paling baik dan tepat.

Proses adalah suatu tahapan atau langkahlangkah yang harus ditempuh dalam melakukan suatu kegiatan. Sebelum membahas mengenai proses pengambilan keputusan dan keterampilan yang harus dimiliki kepala sekolah dalam proses pengambilan keputusan, terlebih dahulu kepala sekolah harus memahami dan mengetahui tentang definisi pengambilan keputusan agar ketika ingin megambil sebuah keputusan kepala sekolah dapat mengatasinya dengan tepat.

Pengambilan keputusan menurut (Gistituati, 2009) adalah proses pemilihan alternatif cara bertindak dari berbagai alternatif yang tersedia untuk memecahkan masalah dalam proses pembuatan keputusan ini merupakan suatu proses yang sistematis.

Menurut (Makawimbang, 2012) menyatakan bahwa pengambilan keputusan adalah suatu tindakan yang diambil dengan menetpakan satu alternatif sesuai dengan keadaan dan kebutuhan dari berbagai alternatif pertimbangan yang dihadapi sehingga dapat memberikan solusi dan jaaln keluar atas masalah yang dihadapi.

Pengambilan keputusan menurut (Siswanto, 2015) adalah serangkaian aktifitas yag dilakukan oeh seorang dalam usaha memecahkan permasalahan yang sedang dihadapi kemudian menetapkan berbagai alternatif yang dianggap paling rasional dan sesuai dengan lingkungan.

Dari pendapat beberapa ahli diatas, dapat saya simpulkan bahwa pengambilan keputusan berarti memilih dan menetapkan 
satu alternatif yang dianggap paling menguntungkan dari beberapa alterantif yang lainnya.

Jadi proses pengambilan keputusan adalah langkah-langkah atau tahapantahapan yang yang saling berkaitan antara tahap yang pertama hingga tahap yang terakhir dalam mengambil keputusan.

Keterampilan dalam proses pengambilan keputusan adalah dimana suatu kemampuan seseorang ketika ingin melakukan sebuah tindakan yaitu melalui proses pengambilan keputusan karena untuk mengambil sebuah keputusan dibutuhkan keterampilan seseorang salah satunya kepala sekolah sebagai pimpinan dalam suatu lembaga pendidikan agar tujuan yang ingin dicapai dapat direalisasikan atau terlaksana dengan baik dan lancar

\section{Proses Pengambilan Keputusan}

Menurut Adair (1985) dalam (Gistituati, 2009) mengemukakan lima langkah di dalam pembuatan keputusan yaitu sebagai berikut:

1. Mengidentifikasi tujuan. Ini merupakan tahap pertama dalam proses pengambilan keputusan dimana mengidentifikasi berarti mengenali mengapa perlu membuat keputusan dalam suatu organisasi atau apa yang menyebabkan organisasi harus membuat keputusan.

2. Mengumpulkan informasi. Setelah kita mengenali sebuah permasalahan yang terdapat dalam sebuah oraganisasi sekolah, kita harus mengumpulkan, mengorganisasikan masalah tersebut. Untuk mengumpulkan informasi tersebut dapat dilakukan dengan cara mencek fakta-fakta yang terjadi, dan opini atau pendapat dari bawahan misalnya guru dan staff di sekolah.

3. Mengembangkan berbagai alternatif. Yaitu kita kumpulkan alternatifalternatif yang di dapat baik itu alternatif dari kepala sekolah maupun dari para guru.
Menilai berbagai alternatif dengan menganalisis konsekunsi dari amasing-masing alternatif, mengukur masing-masing alternatif berdasarkan kriteria yang telah ditetapkan, lalu dilakukan uji coba, dibandinngkan dengan tujuan yang ingin dcapai, setelahh itu memilih sat yang terbaik.

4. Mengimplementasikan alternatif yang telah dipilih. Dalam mengimplementasikan atau melaksanakan keputusan tersebut kepala sekolah juga mengawasi untuk melihat dampaknya dan merivieu kembali mengenai pelaksanaan yang telah dijalankan.

Sedangkan proses pembuatan keputusan menurut Siagian SP (1973) dalam (Makawimbang, 2012) ada tujuh langkah yang perlu diambil dalam usaha memecahkan masalah yaitu sebagai berikut:

1. Mengetahui hakikat dari pada masalah yang dihadapi. Yaitu kita mencari apa permasalahan yang sebenarnya terjadi dan yang perlu mendapat perhatian untuk dipecahkan.

2. Mengumpulkan fakta-fakta dan data yang relevan.

3. Mengolah fakta dari data tersebut. Mengolah fakta-fakta tersebut hingga menjadi sebuah informasi yang kemudian dijadikan dasar pengambilan keputusan.

4. Menentukan beberapa alternatif yang mungkin ditempuh.

5. Memilih cara pemecahan dari alternatif-alternatif yang telah diolah dengan matang.

6. Memutuskan tindakan apa yang hendak dilakukan.

7. Menilai hasil-hasil yang diperoleh sebagai akibat daripada keputusan yang telah diambil. Maksudnya dari tahap ini adalah melakukan evaluasi terhadap keputusan yang diambil. Apakah keputusan yang dijalankan telah sesuai dengan pemecahan masalah 
Sebenarnya banyak sekali langkahlangkah atau proses dalam pengambilan keputusan menurut beberapa ahli, tetapi secara umum dapat saya simpulkan bahwa proses pegambil keputusan yaitu sebagai berikut:

\section{Identifikasi masalah}

Yaitu bagaimana kronisnya sebuah permasalahan di organisasi diukur dengan penyimpangan antara rencana organisasi dengan hasil yang dicapai organisasi. Untuk mengetahui masalah yang sebenernya ada yaitu dengan cara (1) kepala sekolah dapat menguji hubungan sebab akibat; (2) kepala sekolah mencari perubahan-perubahan yang menyimpang dari keadaan yang seperti biasa atau normal; (3) melakukan konsultasi dengan pihak lain atau guru/staf yang mengetahui perjalanan organisasi.

2. Mencari alternatif

Yaitu mengembangkan beberapa alternatif yang dapat dilaksanakan dan harus dipertimbangkan konsekunsi yang mungkin dari masing-masing alternatif. Caranya aitu (1) kepala sekolah dapat melakukannya sendiri atau melalui perjaringan pemikiran para guru/staf/stakeholders untuk mendapatkan keputusan terbaik; (2) kapala sekolah juga dapat mengembagkan brainstorming (smbang saran) yang diminta dari setiap guru/staf.

3. Analisis alternatif

Yaitu kepala sekolah mengevaluasi atau analisis satu persatu secara teliti dengan berpedoman pada kriteria yang telah ditentukan atau mengkaji seluruh kekuatan dan kelemahan. Apakah alternatif yang dijadikan keputusan itu cocokuntuk memecahkan masalah, apakah alternatif itu layak, memuaskan atau memiliki konsekuensi. Jadi harus analisis alternatif terlebih dahulu.

4. Memutuskan alternatif

Yaitu memmutuskan alternatf yang terbaik, yang menguntungkan, yang sedikit kerugiannya dan yang paling mendekati dalam permasalahan untukm emcahkan amsalah. Karena memutuskan alternatif dengan harapan dapat mencaai sasaran yang diinginkan yaitu masalah dapat terselesaikan.

5. Implementasi keputusan

Yaitu pilihan harus dilaksanakan secara efekif untuk merealisasikan tujuan yang telah ditetapkan. Kepala sekolah perlu membuat rencana implementasi ini dengan seoperasional mungkin dlam bentuk prosedurprosedur dan rincian-rincian kegiatan sehingga para guru atau staf mudah melaksanakannya. Prosedur implementasi keputusan yaitu (1) menyusun jadwal pelaksanaan; (2) membagi tugas pelaksanaanya; (3) menetapkan langkah-langkah permbuatan laporan; (4) pengawasan diri agar pelaksanaan sesuai hasil keputusan.

6. Evaluasi

Evaluasi merupakan tahap terakhir dalam proses pembuatan keputusan yang tidak boleh dilewatkan. Karena setiap implementasi pastinya harus kita nilai mengenai pelaksanaan yang kita jalankan. Evaluasi disini adalah melakukan pengukuran berkala mengenai keluaran yang nyata atau bisa kita sebut dengan hasil. Keluaran nyata tersebut dibandingkan dengan keluaran yang direncanakan dan apabila terjadi penyimpangan perlu diadakan perubahan dalam pemecahan yang dipilih pelaksanaanya atau dalam sasaran semula, apabila sasaran semula harus diubah, maka proses pengambilan keputusan secara keseluruhan perlu diulang kembali. Mungkin terdapat kesalahan dalam memilih alternatif yang tepat atau dalam implementasi dan yang lainnya yang menyebabkan keputusan tersebut tidak sesuai atau tidak tepat.

Agar keputusan yang diambil oleh kepala sekolah tepat, maka kepala sekolah harus melibatkan dasar-dasar pengambilan keputusan sebagaimana menurut 
(Makawimbang, 2012) dasar-dasar membuat keputusan yaitu sebagai berikut:

1. Pengambilan keputusan berdasarkan intuisi

Yaitu intuisi/perasaan lebih bersifat subjektif yaitu mudah terkena sugesti, pengaruh luar, dan faktor kejiwaan lain.

2. Pengambilan keputusan berdasarkan rasional

Yaitu lebih bersifat objektif dalam masyarakat.

3. Pengambilan keputusan berdasarkan fakta

Yaitu pengambilan keputusan yang dibutuhkan dengan data dan informasi.

4. Pengambilan keputusan berdasarkan pengalaman

Yaitu sebelum mengambil keputusan, kepala sekolah mengingat apakah permasalahan atau kasus seperti ini sebelumnya pernah terjadi atau tidak. Jika pernah terjadi sebelumnya, maka kepala skeolah tinggal melihat apakah permasalahan tersebut sama atau tidak dengan situasi dan kondisi saat ini. Jika sama maka kepala sekolah dapat menerapkan cara yang sebelumnya tersebut. Karena pengalaman dapat dijadikan pedoman dalam meyelesaikan masalah.

5. Pengambilan keputusan berdasarkan wewenang

Yaitu bayak diterima oleh para bawahan seperti guru/staf, juga apabila didasari dengan wewenang yang resmi akan lebih permanen sifatnyya.

Upaya yang dilakukan untuk meningkatan kemampuan kepala sekolah dalam pengambilan/pembuatan keputusan menurut (Rahayu, 2014)) adalah sebagai berikut:

1. Meningkatkan kemampuan kecerdasan/ intelegensi

Untuk membuat keputusan tidaklah jauh-jauh dari pengetahuan yang dimilki seseorang. Karena dalam membuat keputusan dibutuhkan analisa/berpikir yang tinggi. Kemampuan itu memungkinkan kepala sekolah mengarahkan pemikiran anggotanya dalam menyusun perencanaan dan menetepkan keputusan yang tepat dalam mewujudkan beban tugas organisasinya. kepala sekolah juga harus mampu membantu kelompoknya untuk menyelesaikan masalah.

Biasanya semakin luas pengetahuan seseorang maka akan semakin mudah dalam mengambil suatu keputusan.

2. Meningkatkan keterampilan/ keahlian dibidangnya

Tidak hanya pengetahuan saja yang harus dimiiki oleh seorang kepala sekolah, tetapi ketrampilan dibidangnya juga harus dikuasi agar pada saat implementasi kepala sekolah bisa menerapkannya bersama guru/staf.

Kepala sekolah juga harus selalu mengikuti perkembangan dan kemajuan dibidang kerjanya agar mampu memenuhi tuntutan masyarakat dan teknologi serta mampu melihat hubungan bidang tugasnya dengan bidang lain yang mempengaruhinya. Pengetahuan dan pengalaman yang cukup dibidangnya seorang kepala sekolah akan mampu melihat kedepan dalam meningkatkan perkembangan organisasi atau lembaga yang dipimpinnya. Dengan keahlian yang cukup maka kepala sekolah akan bisa mengambil keputusan dengan tepat.

3. Mengembangkan sikap kreatif, penuh inisiatif untuk perkembangan yang lebih baik

Dalam pengambilan keputusan dibutuhkan kepala sekolah yang kreatif yaitu memikirkan ide/gagasan terbarunya. Kepala sekolah langsung sigap dan peka terhadap segala sesuatunya 
tanggung jawab atas akibat dari hasil keputusan yang diambilnya.

\section{Saran}

Bagi kepala sekolah diharap tetap memahami tantang proses pengambilan keputusan. Mampu meningkatkan keterampilan dalam mengambil/ membuat keputusan seperti dari segi kecerdasan/intelegensi, ahli dibidangnya, memiliki ide/gagasan terbaru dan peenuh insisiatif, dapat mengendalikan ]kecerdasan emosionalnya, dan berani dan bertanggung jawab atas hasil keputusan yang diambilnya.

Untuk guru dan staf lebih terbuka lagi untuk membantu dalam proses pembuaan keputusan seperti memberikan sumbangan ide atau solusi alternatifnya.

\section{DAFTAR PUSTAKA}

Gistituati, N. (2009). Manajemen

Pendidikan: Budaya dan

Kepemimpinan Organisasi. Padang:

UNP Press.

Makawimbang, J. H. (2012).

Kepemimpinan Pendidikan ang

Bermutu. Bandung: Alfabeta.

Rahayu, P. (2014). Peningkatan

Kemampuan Kepala Sekolah Dalam

Pengambilan Keputusan.

Siswanto. (2015). Pengantar Manajemen.

Jakarta: Bumi Aksara. 